\section{Carbon and oxygen isotopic compositions of the carbonates from the laterite and hydrothermal- sedimentary ores of the Tomtor ultramafic carbonatite complex (Russia)}

SERGEY ZHMODIK ${ }^{1}$, VIKTOR PONOMARCHUK ${ }^{2}$, ELENA LAZAREVA ${ }^{2}$ AND ALEKSANDR PYRYAEV ${ }^{2}$

${ }^{1}$ Institute of Geology and Mineralogy SB RAS

${ }^{2}$ Institute of Geology and Mineralogy SB RAS, Novosibersk, Russian Federation

Presenting Author: zhmodik@igm.nsc.ru

Zone of the weathering (laterite) over carbonatites from Brazil (Araxa, Catalao, Madeira), Australia (Mt. Weld, Stromberg), Tanzania (Ngulla), Russia (Tomtor) and others are important sources of REE, $\mathrm{Nb}$. Tomtor ultramafic carbonatite complex rocks in the boreholes up to a depth of $500 \mathrm{~m}$ were studied. Structural-morphological and isotopic evidence of large-scale participation of microbiota (bacteria, plant residues) in the formation of the Nb-REE-zone weathering for the Tomtor ultramafic carbonatite complex (lower ore horizon) and highly dispersed hydrothermal-sedimentary ultra-rich $\mathrm{Nb}$-REE ores of the upper ore horizon (UOH) was revealed (fig.1; Dokl. Earth Sci., 2021, 496, 154-157)). The $\delta^{13} \mathrm{C}$ of carbonates from the rocks is: for calcite from -7 to- $41 \%$ (PDB), for dolomite/ankerite from -7 to- $75 \%$, and for siderite/rhodochrosite from -7 to $-48 \%$.

Interval $\delta^{18} \mathrm{O}$ for calcite, from 13 to $18 \%$ (SMOW), for dolomite / ankerite and siderite / rhodochrosite, from 14 to $23 \%$. In some horizons, the difference in $\delta^{13} \mathrm{C}$ in sonicated calcite and dolomite / ankerite reaches $20 \%$ (PDB), which indicates a different time of their formation. On the formation of a specific weathering crust based on Tomtor carbonatites with the participation of: deuteric, hydrothermal fluids with varying contents of $\mathrm{Fe}, \mathrm{Mn}$ and $\mathrm{H}_{2} \mathrm{O} / \mathrm{CO}_{2}$ ratio at a temperature of 300 $80^{\circ} \mathrm{C}$; methane, organic nature, processed by microbes; microorganisms in the redistribution and formation of ultra-rich REE-ores (UOH). The identified and described features of the Tomtor deposit ore formation can be expected at the Catalao I, the Morro dos Seis Lagos Nb (Ti, REE), Mt.Weld deposits, given the geological similarity and the presence of deep lateritization.

This work was supported by the Russian Science Foundation, project No. 18-17-00120.

Fig.1 Biomorphic structures (SEM data) in Nb-REE-rich ores of the Tomtor deposit. A, A layered lithified microbial mat consisting of rod-shaped tubular microfossils (RTM) composed of halloysite-monazite aggregate (HMA) and coccoid microfossils (CM) in the fossilized glycocalyx (the middle part), composed of aluminophosphates - APS; B, the microbial mat, consisting of RTM (HMA); C - RTM colonies; D, APS-fossilized coccoid bacteria; E, a concentric-zonal aggregate, consisting of ball-shaped biomorphic particles of pyritic and APS composition.

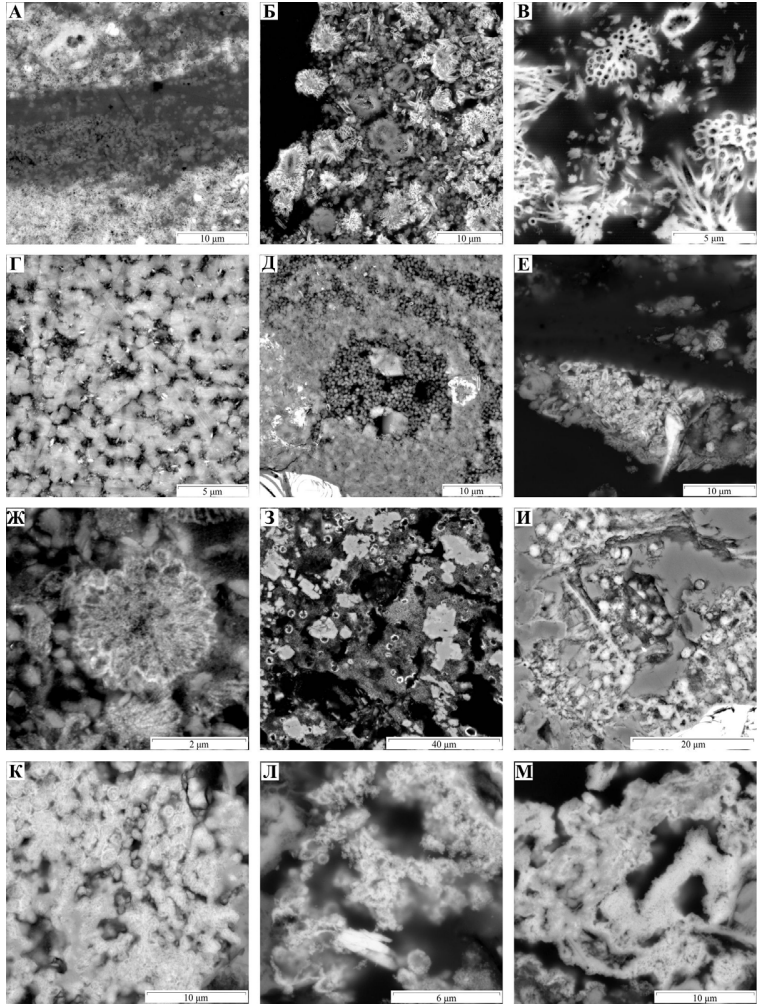

